\title{
COST EFFICIENCY OF THE CZECH AND SLOVAK BANKING SECTORS: AN APPLICATION OF THE DATA ENVELOPMENT ANALYSIS
}

\author{
Iveta Palečková \\ Department of Finance and Accounting, School of Business Administration, Silesian University, \\ Univerzitní náměstí 1934/3, 73340 Karviná, Czech Republic \\ E-mail: paleckova@opf.slu.cz
}

\begin{abstract}
The aim of the paper is to estimate the cost efficiency of the Czech and Slovak commercial banks within the period 2010-2014. For empirical analysis the Data Envelopment Analysis input-oriented model with variable returns to scale is applied on the data of the commercial banks. The intermediation approach is adopted to define the inputs and outputs. The Czech commercial banks are more cost efficient than Slovak commercial banks. The development of average cost efficiency is similar in the Czech and Slovak banking industry. The most efficient Czech banks are Česká spořitelna and Sberbank in the Czech banking sector, the most efficient Slovak bank is Privatbanka with $100 \%$ efficiency.
\end{abstract}

Keywords: cost efficiency, commercial bank, Czech Republic, Data Envelopment Analysis, intermediation approach, Slovakia.

JEL Classification: G21, C14.

\section{Introduction}

The examination of banking efficiency has fueled a large body of literature globally, and is of vital importance from both a microeconomic and a macroeconomic point of view (Berger, Mester 1997). The Czech and Slovak financial system is bank-based, thus the investigation of efficiency of these banks is important topic.

The aim of the paper is to estimate the cost efficiency of the Czech and Slovak commercial banks within the period 2010-2014. For examination of efficiency, two major approaches are used in empirical literature, the parametric and non-parametric. The non-parametric (mathematical programming) approach is represented mainly by the Data Envelopment Analysis (DEA) and the Free Disposal Hull method, while the parametric (econometric) approach is represented by the Stochastic Frontier Analysis and the Thick Frontier Analysis. Stavárek and Polouček (2004) stated that both approaches use different techniques to envelop a data set with different assumptions for random noise and for the structure of production technology. These assumptions generate the strengths and drawbacks of both approaches that can be grouped under two categories. We estimate the cost efficiency using the nonparametric approach, namely the Data Envelopment Analysis.

The structure of the paper is following. Second chapter presents the previous studies regarding to the cost efficiency in the Czech and Slovak banking sector and selection of inputs and outputs using in estimation of banking efficiency. Next section described the methodology about cost efficiency and data. Empirical analysis and results are in fourth section where the cost efficiency in the Czech and Slovak banking industry is estimated. Last section concludes the paper with discussion of results and findings.

\section{Literature review}

This section presents the previous studies regarding to banking efficiency. First empirical literature about the selection of variables is described. Next the empirical analysis of cost efficiency of the Czech and Slovak banking sector is introduced.

\subsection{Selection of inputs and outputs}

For the estimation of efficiency are first defined used inputs and outputs. As Berger and Humphrey (1997) reported in the empirical literature there is not consensus which inputs and outputs to be used in the analysis of banking efficiency. Several major approaches were developed in the empirical literature that define the relationship of inputs and outputs in the behavior of financial institutions. Firstly, an intermediation approach was introduced by Sealey and Lindley (1977), it suggests that the main purpose of banks is to transform their liabilities (de- 
posits) into loans (assets). The intermediation approach assumes that the main aim of a commercial bank is to create output, defined as loans and investment, whilst using liabilities (including deposits), labor, and capital as inputs (Bod'a, Zimková 2015). Therefore, loans and other assets are considered to be the banks' outputs, while deposits and other liabilities are inputs (Jimborean, Brack 2010). In the underlying philosophy of this approach a commercial bank is a chief financial intermediary in economy and its primary role is to transmute deposits into loans, which pre-determines the treatment of deposits as inputs and loans as outputs (Bod'a, Zimková 2015).

The second approach is the production approach (sometimes referred to as service-oriented approach or user-cost approach), it was presented in study of Sherman and Gold (1985) and it can also be defined as a value-added approach. Production approach focuses on the services provided to clients and the bank assumes that the aim is to produce bank liabilities (deposits) and loans (assets) and other services. Thus, it assumes that the aim of commercial banks is to produce deposits (liabilities) as well as loans (assets) and other services (Bod'a, Zimková 2015). Production approach thus has two main drawbacks that ignores the interest costs and requires information about the number of accounts and cost allocation (Kamecka 2010). Benston (1965) was one of the first author who used this approach in the study. Bod'a and Zimková (2015) stated that this variant of the approach that considers deposits to be an output together with loans and the interest income is called the service-oriented approach. Berger et al. (1987) followed Benston's approach and add an alternative specification under the intermediation approach. Other modification of production approach is the user costs approach developed by Hancock (1991) and deposits are specified as both inputs and outputs of the cost/profit function of a bank (Bod'a, Zimková 2015). Hancock (1991) specified that demand deposits would be classified as outputs, while time deposits would be classified as inputs.

Production and mediating approach are the best known and most widely used in quantifying the effectiveness bank (Sealey, Lindley 1977). Third, the approach in terms of assets (asset approach) recognizes the essential role of financial institutions as the creator of loans. In essence, this stream of thought a variant of the mediation approach, but the output is defined as a condition of the loan and investment property (Favero, Papi 1995).
Last profitable approach is the latest approach to the relationship of inputs and outputs. It was defined by Berger and Mester (2003), who reported that using a profit approach can be taken into account unmeasured changes in quality of banking services, including higher incomes paid for better quality and can help capture the objective of maximizing profits by including costs and revenues. These changes should appear especially after any major change in the disposable income of citizens (Kamecka 2010).

Casu and Molyneux (2003) stated that there is no all-encompassing theory of the banking firm and no agreement on the explicit definition and measurement of banks' inputs and outputs.

Berger and Humphrey (1997) confirmed that, although there is no perfect approach, but the intermediation approach may be more appropriate for evaluating entire financial institutions because this approach is inclusive of interest expenses, which often account for one-half to two-thirds of total costs. Moreover, the intermediation approach may be superior for evaluating the importance of frontier efficiency to the profitability of financial institutions, since the minimization of total costs, not just production costs, is needed to maximize profits (Casu, Molyneux 2003).

As stated Tortosa-Ausina (2002), the opportunity for using of each of these approaches will vary depending on the circumstances. Intermediation approach is considered to be more relevant for the banking sector, where the largest share of activity consists of the transformation of funds raised (deposits) to loans or investments.

Thus, Casu and Molyneux (2003) used intermediation approached and specified two outputs: total loans and other earning assets and two inputs: total costs (interest expenses, non-interest expenses, personnel expenses) and total deposits.

Also Jimborean and Brack (2010) considered the intermediation approach and as inputs they quantified fixed assets, labor measured as full-time equivalents; and borrowed funds measured as the long term and subordinated debt. They derived input prices per bank as depreciation relative to fixed assets, personnel expenses and interest expenses relative to total borrowed funds. They defined the volume of customer deposits, the volume of customer credits and the net fee and commission income as outputs.

Zimková (2015) used intermediation approach and she chose two inputs: number of employees and wages as a cost of employees and deposits and interest rate as a cost of deposits and one outputs: 
loans. Also Kočišová (2014) adopted the intermediation approach and considered three inputs, especially deposits, number of employees and fixed assets and their prices referred to total interest expenses, personnel expenses and other operating expenses. The outputs she consider total loans and other earning assets.

On the contrary, Zimková and Bod'a (2015) used the production approach and as inputs they included labor and fixed assets and as outputs they took deposits and loans.

Bod'a and Zimková (2015) compared three approached, namely the intermediation approach, service-oriented approach and profit-oriented approach and found that general impressions of the efficiency status of individual banks as obtained within the three approaches are similar in most cases.

\subsection{Cost efficiency in the Czech and Slovak banking sectors}

Matoušek and Taci (2005) estimated the cost efficiency of the Czech banking industry during the 1990s using Distribution Free Approach. They concluded that foreign banks were more efficient than others.

Fries and Taci (2005) examined the cost efficiency of the 15 post-communist countries and found that private banks were more efficient than state-owned banks and privatized banks with majority foreign ownership were the most efficient and those with domestic ownership were the least.

Řepková (2012, 2013) estimated cost efficiency of the Czech commercial banks using the parametric approach Stochastic Frontier Approach and found that the average cost efficiency was increasing during the period 2001-2010. The studies also found that the largest banks in the market were more efficient than medium-sized and small banks.

Repková and Miglietti (2014) estimated cost efficiency of the Slovak commercial banks using the Stochastic Frontier Approach and they found that the average cost efficiency decreased in the Slovak banking sector within the period 2003-2012. In the Slovak banking industry, the group of small and medium-sized banks were more efficient than the largest banks.

Kočišová (2014) estimated the cost, revenue and profit efficiency of the Czech and Slovak banking sector using the DEA model. She concluded that on average commercial banks were the most revenue efficient and the average cost efficiency decreased from score of $77 \%$ in 2009 to $72 \%$ in 2012 , and in 2013 increased to value $77 \%$. Results also showed that the Czech banks were more cost efficient than the Slovak ones during the period 20092013. Thus, she claimed that the level of potential costs savings was in case of Slovak banks higher.

Zimková (2015) employed the tradition and new approach of the Data Envelopment Analysis to measure the cost efficiency of the Slovak commercial banks. Her findings showed that in the case of the traditional approach, which assumes that prices of inputs are exogenously given, transformation of human sources and deposits into loans was successfully achieved by four banking institutions. A new measure, which allows endogenity of the input prices, transformation of human sources and deposits into loans was successfully achieved by eight banking institutions under the research.

Zimková and Bod'a (2015) applied the DEA approach to examine the cost efficiency of the Slovak banking sector in 2012. Their results showed that the most cost efficient were two largest Slovak commercial banks, namely Slovenská sporitelňa and Všeobecná úvěrová banka.

\section{Methodology and data}

In the chapter is describes used methodology, especially the Data Envelopment Analysis approach. In the second part of this chapter the data and selection of variables are presented.

\subsection{Data envelopment analysis}

The study of the efficient frontier was introduced by Farrell (1957), which defined a simple measure of firm's efficiency. He suggested that the efficiency of any firm consists of two parts, i.e. technical and allocative efficiency. Farrell (1957) described the technical efficiency as a firm's ability to produce maximum output from a given set of inputs. Allocative efficiency means the ability of a firm to use these inputs in an optimal proportion with respect to their respective prices (Farrell 1957). It is clear that data of prices are necessary for this kind of efficiency. Farrell (1957) also called it as a cost efficiency.

Data Envelopment Analysis utilizes techniques such as a mathematical programming technique that measures the relative efficiency of the production units, which are described in the literature as a Decision Making Unit (DMU), in comparison with other similar DMU, with the restriction that all DMU lies at or below the level of efficiency (Seiford, Thrall 1990). The term Decision Making Unit was used for the first time in the CCR model proposed in Charnes et al. (1978). Efficient production units are 
able to use the optimum amount of inputs or produce an optimum amount of outputs. Production units are units that use inputs and produce outputs.

The Data Envelopment Analysis can handle large numbers of variables and elations and this relaxes the requirements that are often encountered when one is limited to choosing only a few inputs and outputs because the techniques employed will otherwise encounter difficulties (Cooper et al. 2007).

The Data Envelopment Analysis was first introduced by Charnes et al. (1978). They extended Farrell's (1957) work and succeeded in in establishing DEA as a basic for efficiency analysis. CCR model, which was called by the study Charnes, Cooper and Rhodes, assume constant returns to scale (CRS). Banker et al. (1984) modified CCR model of the variable returns to scale (VRS) and it is called BCC model (according to a study of Banker, Charnes and Cooper).

The values of efficiency computed in the BCC model is called pure technical efficiency. The BCC model eliminates inefficiencies caused by inadequate size of production units. The assumption of variable returns to scale provides a measurement of pure technical efficiency, which is a measure of technical efficiency devoid of effects of scale efficiency. Figure 1 shows CCR model which is model on the assumption of constant returns to scale of activities as depicted for the production frontier in the single input-single output case.

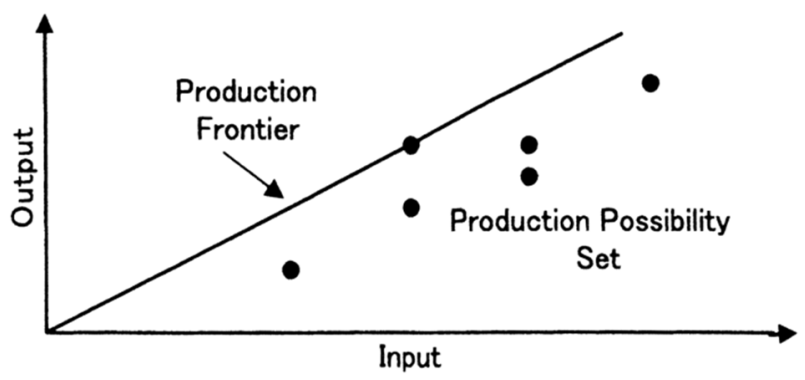

Fig. 1. Production Frontier of the CCR model. (Source: Cooper et al. 2007)

Production frontier of the BCC model with one input and one output is presented in Figure 2. The BCC model has its production frontiers spanned by the convex hull of the existing DMUs. The frontiers have piecewise linear and concave characteristics which leads to variable returns to scale characterizations with increasing returns to scale occurring in the first solid line segment followed by decreasing returns to scale in the second segment and constant returns to scale occurring at the point where the transition from the first to the second segment is made (Cooper et al. 2007).

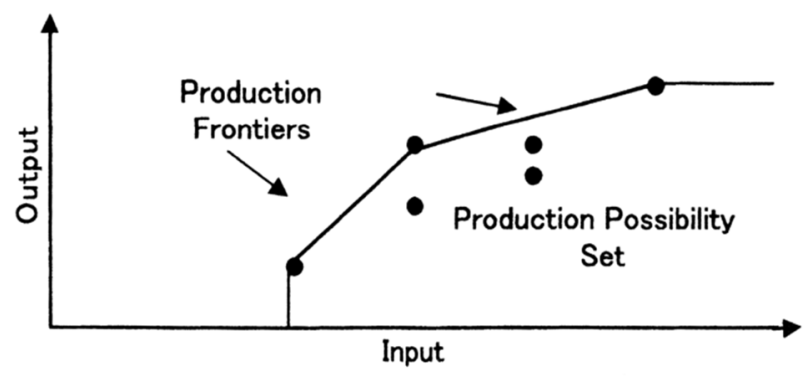

Fig. 2. Production Frontier of the BCC model. (Source: Cooper et al. 2007)

We measure cost efficiency using DEA method. Farrell (1957) proposed a measure of cost efficiency, which assumes that prices are fixed and known, although they may possibly be different between the DMUs. Farrell (1957) refers to it as a measure of price efficiency but the more commonly used term is allocative efficiency. Methodology used in this paper is followed the study of Cooper et al. (2007). The optimal point $\mathrm{C}$ is obtained as the optimal solution $x^{*}$ of the following linear program (Farrell 1957):

$$
\begin{gathered}
c x^{*}=\min c x, \\
x, \lambda,
\end{gathered}
$$

subject to

$$
\begin{gathered}
x \geq X \lambda, \\
y_{0} \leq Y \lambda, \\
\lambda \geq 0,
\end{gathered}
$$

where $c=\left(c_{1}, \ldots, c_{m}\right)$ is the common unit inputprice or unit-cost vector, $x$ represents combinations of the input amounts that are needed to produce the same amount of a single output, $y_{0}$ is the output of the DMU. $X$ is matrix of input and $Y$ represents matrix of output. $\lambda$ is the weight of the DMU.

More detailed methodology about cost efficiency is describe in Cooper et al. (2007) or Camanho and Dyson (2005).

\subsection{Data and selection of variables}

The data set consist of 24 commercial banks from the Czech Republic and Slovakia. Especially, 14 Czech commercial banks and 10 Slovak commercial banks. We do not include the specialized financial institutions, building societies, mortgage banks, foreign bank branches and other specialized institutions. These banks represents more than $70 \%$ share of total assets of banking industry in the Czech Republic as well as in Slovakia. Thus, the sample of banks is representative and results of the paper could be interpreted as results of banking sectors. 
Due to the homogeneity of the data set only commercial banks are analyzed in this paper. The data is obtained from the annual reports of the Czech and Slovak commercial banks during the period 2010 2014.

This paper adopted the intermediation approach, which assumes that the commercial bank collects deposits and transform them into loans. Following Kočišová (2014) or Zimková (2015) we employed three inputs and their prices and one output with the price. As inputs we chose deposits (TD), fixed assets (FA) and number of employees (NE). The price of deposits is interest expenses (IE), the price of fixed assets is other operating expenses (OOE) and the price of number of employees is personal expenses. As the output we chose total loans and the price is interest income.

Table 1. Selection of variables (Source: compiled by the author)

\begin{tabular}{l|l}
\hline Variable & Price \\
\hline Inputs & Interest expenses \\
\hline Total deposits & Other operating expenses \\
\hline Fixed assets & Personal expenses \\
\hline Number of employees & \multicolumn{2}{|l}{} \\
\hline Output & Interest income \\
\hline \multicolumn{2}{l}{ Total loans }
\end{tabular}

Table 1 summarized the selection of individual variables (inputs and output) and their prices.

Table 2. Descriptive Statistics of selection of variables in the Czech banking sector (in mil CZK) (Source: author's calculation)

\begin{tabular}{|c|c|c|c|c|c|}
\hline & 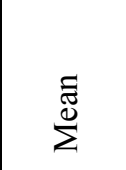 & & $\underset{\Xi}{. \Xi}$ & $\begin{array}{l}\text { 志 } \\
\text { 离 } \\
\sum_{\Sigma}\end{array}$ & 岕 \\
\hline $\mathrm{TD}$ & 175648 & 62086 & 904 & 674304 & 216091 \\
\hline IE & 2634 & 942 & 3 & 14025 & 3596 \\
\hline FA & 2456 & 574 & 2 & 15410 & 4165 \\
\hline $\mathrm{OOE}$ & 2569 & 596 & 4 & 11843 & 3277 \\
\hline $\mathrm{NE}$ & 2714 & 610 & 40 & 10760 & 3470 \\
\hline $\mathrm{PE}$ & 2071 & 640 & 22 & 7908 & 2498 \\
\hline $\mathrm{TL}$ & 132461 & 45944 & 0 & 472886 & 155667 \\
\hline II & 10072 & 3565 & 5 & 39564 & 12753 \\
\hline
\end{tabular}

Table 2 describes the descriptive statistics of selection of inputs and outputs of the Czech commercial banks.
Table 3. Descriptive Statistics of selection of variables in the Slovak banking sector (in mil EUR). (Source: author's calculation)

\begin{tabular}{l|c|c|c|c|c}
\hline & Mean & Median & Minimum & Maximum & St. Dev. \\
\hline TD & 3682 & 2750 & 378 & 9684 & 2941 \\
\hline IE & 53 & 48 & 9 & 152 & 36 \\
\hline FA & 58 & 30 & 1 & 239 & 57 \\
\hline OOE & 69 & 36 & 2 & 242 & 67 \\
\hline NE & 1809 & 1176 & 134 & 4062 & 1429 \\
\hline PE & 49 & 31 & 5 & 113 & 39 \\
\hline TL & 3244 & 2087 & 180 & 8142 & 2633 \\
\hline II & 226 & 179 & 19 & 573 & 186 \\
\hline
\end{tabular}

The descriptive statistics of selection of inputs and outputs of commercial banks in Slovakia are described in Table 3.

\section{Empirical analysis and results}

For empirical analysis we used the MaxDEA Pro 6.7 software. MaxDEA is specialized software for estimation several modified Data Envelopment Analysis models. MaxDEA is developed by Cheng Gang. We estimated cost efficiency using the inputoriented model with variable returns to scale (BCC model).

We estimated efficiency of the Czech and Slovak banking sector together and the results are presented individually for the Czech and Slovak banking sector for better lucidity.

Table 4 presents the descriptive statistics of results of cost efficiency in the Czech and Slovak banking industry. We can see that on average the Czech commercial banks are more cost efficient than commercial banks in Slovakia. The average median value is also higher in the Czech commercial banks then in Slovak commercial banks.

The average value of efficiency of the Czech banking sector was in range $68-75 \%$. The average value of the Slovak banking sector reached the value of $47-75 \%$. Thus, we found only marginal differences in efficiency in the Czech banking sector. On the other hand, the higher difference between the lowest and highest efficient bank (minimum and maximum value of efficiency) is registered in the Czech banking sector than in Slovak banking sector. When we compare the median value of banking efficiency, the Czech commercial banks were higher values than Slovak commercial banks. 
Table 4. Descriptive Statistics of Cost Efficiency in the Czech and Slovak Banking Sector. (Source: author's calculation)

\begin{tabular}{l|c|c|c|c|c}
\hline & 2010 & 2011 & 2012 & 2013 & 2014 \\
\hline Czech banking sector \\
\hline Mean & 0.6913 & 0.6787 & 0.7427 & 0.7471 & 0.7293 \\
\hline Median & 0.7334 & 0.6879 & 0.7801 & 0.7979 & 0.8249 \\
\hline Minimum & 0.2799 & 0.3101 & 0.3329 & 0.3481 & 0.1851 \\
\hline Maximum & 1 & 1 & 1 & 1 & 1 \\
\hline St.Dev. & 0.2387 & 0.2586 & 0.2651 & 0.2524 & 0.2974 \\
\hline Slovak banking sector & 0.7502 & 0.6647 & 0.7186 & 0.6766 & 0.4709 \\
\hline Mean & 0.6993 & 0.6406 & 0.7113 & 0.6245 & 0.4329 \\
\hline Median & 0.491 & 0.4383 & 0.5346 & 0.4955 & 0.2804 \\
\hline Minimum & 0.4881 & 1 & 1 & 1 & 1 \\
\hline Maximum & 1 & 1 & 0.179 & 0.2192 \\
\hline St.Dev. & 0.2000 & 0.2038 & 0.1598 & 0.1741 & \\
\hline Czech and Slovak banking sectors \\
\hline Mean & 0.7169 & 0.6729 & 0.7326 & 0.7195 & 0.6282 \\
\hline Median & 0.7334 & 0.6680 & 0.7188 & 0.7437 & 0.5712 \\
\hline Minimum & 0.2799 & 0.3101 & 0.3329 & 0.3481 & 0.1851 \\
\hline Maximum & 1 & 1 & 1 & 1 & 1 \\
\hline St.Dev. & 0.2199 & 0.2326 & 0.2233 & 0.2234 & 0.2939 \\
\hline
\end{tabular}

For better clarify of the development of cost efficiency of the banking sectors we typify the average cost efficiency of the Czech commercial banks (CZ), Slovak commercial banks (SK) and the Czech and Slovak banking sectors together $(\mathrm{CZ}+\mathrm{SK})$ in Figure 3.

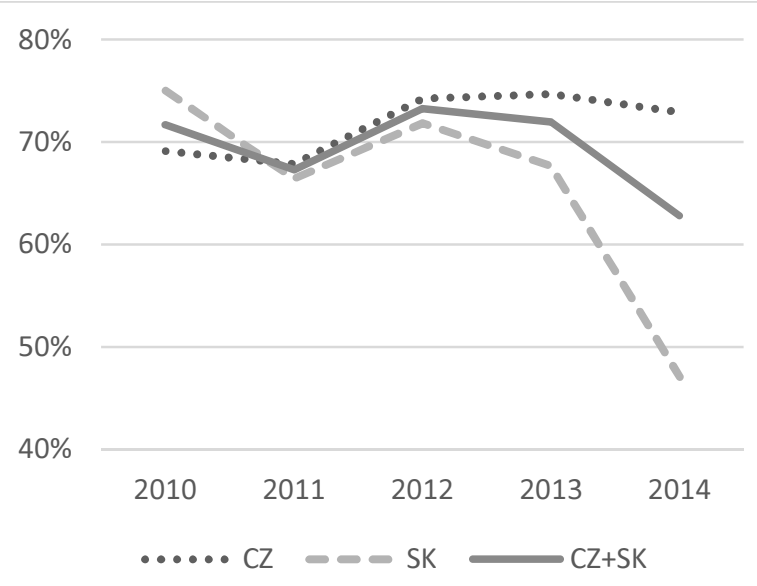

Fig. 3. Average cost efficiency of the Czech and Slovak banking sector (Source: author's calculation)

The development in cost efficiency is very similar in the Czech and Slovak banking industry. The average cost efficiency slightly decreased in 2010 probably as a result of financial crisis. The interest rate decreased in both countries. This decrease in interest rate was reflected in results of cost efficiency. Other decrease in cost efficiency was in the period 2013-2014. In this period we register significant decrease in interest income in most of commercial banks. Banks in these period provided loans but the interest rate on loans was decreased. Thus, the total loans were increasing but the interest income was decreasing. Thus it had a negative impact on cost efficiency. On the other hand, we also register the decrease in interest rate on deposits.

Table 5. Cost efficiency of the Czech Commercial Banks (Source: author's calculation)

\begin{tabular}{l|c|c|c|c|c}
\hline & 2010 & 2011 & 2012 & 2013 & 2014 \\
\hline Air Bank & & 0.31 & 0.33 & 0.48 & 0.37 \\
\hline Ceska sporitelna & 1 & 1 & 1 & 1 & 1 \\
\hline CSOB CZ & 0.28 & 0.48 & 0.56 & 0.70 & 0.80 \\
\hline Equa banka & 0.57 & 0.54 & 0.68 & 0.74 & 0.62 \\
\hline $\begin{array}{l}\text { Evropsko-ruska } \\
\text { banka }\end{array}$ & 0.73 & 0.62 & 0.63 & 0.42 & 1 \\
\hline Expobank & 0.78 & 0.83 & 1 & 0.98 & 0.64 \\
\hline Fio banka & 0.39 & 0.35 & 0.35 & 0.35 & 0.19 \\
\hline GE Money Bank & 0.67 & 0.76 & 0.88 & 0.85 & 0.85 \\
\hline JT Banka & 0.59 & 0.50 & 0.57 & 0.65 & 0.57 \\
\hline Komercni banka & 0.79 & 0.92 & 0.98 & 0.91 & 0.94 \\
\hline PPF banka & 0.40 & 0.35 & 0.41 & 0.39 & 0.23 \\
\hline Raiffeisenbank & 0.79 & 1 & 1 & 1 & 1 \\
\hline Sberbank CZ & 1 & 1 & 1 & 1 & 1 \\
\hline UniCredit Bank CZ & 1 & 0.84 & 0.99 & 1 & 1 \\
\hline
\end{tabular}

Table 5 reports the average cost efficiency of the commercial banks in the Czech Republic. The efficiency is in range from 0 to 1 , respectively from 0 to $100 \%$. The efficiency score of $100 \%$ means that DMU operates on $100 \%$ efficient frontier. The results show that the most efficient banks are Česká spořitelna and Sberbank that operate in 100\% efficient frontier. Fio banka, Air Bank and Evropskoruska banka are relatively new banks that have operated in the Czech banking sector since 2009 or 2011 (Air Bank) in the banking sector. Fio banka, PPF banka and Air Bank are the lowest efficient banks in the Czech banking sector.

One of the most advantage of DEA model is that this model can explain the reasons of inefficiency for inefficient DMU, i.e. bank. We estimated the input-oriented model, thus we analyze the reason of inefficiency in inputs. In all inefficient banks the main reason of inefficiency is the excess of clients' deposits in banks' balance sheet. The DEA model shows the optimal value of inputs for each 
inefficient bank to be efficient. Other reason is number of employees and the high value of cost of fixed assets is in Expobank or in Air Bank.

The average value of cost efficiency of the Slovak commercial banks is reported in Table 6 . The most efficient banks is Privatbanka that operate in $100 \%$ efficient frontier. Next most efficient bank are OTP Bank and UniCredit Bank with average efficient frontier of $81 \%$. The lowest efficient banks are Postova banka, Tatrabanka and Slovenska sporitelna. Postova banka reached the average efficiency $46 \%$, Tatrabanka was average efficiency score of $47 \%$ and Slovenska sporitelna reached the average value of $49 \%$. Tatrabanka and Slovenska sporitelna belongs to the group of the largest banks in the industry.

Table 6. Cost efficiency of the Slovak Commercial Banks (Source: author's calculation)

\begin{tabular}{l|c|c|c|c|c}
\hline & 2010 & 2011 & 2012 & 2013 & 2014 \\
\hline CSOB SK & 0.65 & 0.54 & 0.59 & 0.56 & 0.28 \\
\hline OTP Bank & 0.96 & 0.86 & 0.87 & 0.84 & 0.52 \\
\hline Postova banka & 0.49 & 0.45 & 0.53 & 0.51 & 0.33 \\
\hline Primabanka & 0.96 & 0.72 & 0.76 & 0.74 & 0.49 \\
\hline Privatbanka & 1 & 1 & 1 & 1 & 1 \\
\hline Sberbank SK & 0.96 & 0.79 & 0.80 & 0.77 & 0.52 \\
\hline Slovenska sporitelna & 0.52 & 0.44 & 0.56 & 0.54 & 0.37 \\
\hline Tatrabanka & 0.58 & 0.44 & 0.56 & 0.50 & 0.29 \\
\hline UniCredit Bank SK & 0.75 & 0.84 & 0.85 & & \\
\hline VUB & 0.65 & 0.56 & 0.66 & 0.62 & 0.43 \\
\hline
\end{tabular}

The main reason of inefficiency of the inefficient banks is the excess of clients' deposits in balance sheet of the most of the Slovak commercial banks. For example in CSOB Slovakia other reason of inefficiency was the number of employees. This bank would be more efficient if it decrease deposits and number of employees.

\section{Conclusion and discussion}

The aim of the paper was to estimate the cost efficiency of the Czech and Slovak commercial banks within the period 2010-2014. For estimation of cost efficiency we employed the Data Envelopment Analysis. It was used input-oriented model with variable returns to scale.

This study found that average cost efficiency was higher in the Czech banking sector then in Slovak banking sector. This results confirm the results of Kočišová (2014) who also found that the Czech banks were more cost efficient the Slovak banks within 2009-2013. The average cost efficiency reached value of $68-75 \%$ in the Czech banking industry and $47-75 \%$ in Slovak banking sector. The development of cost efficiency shows that the development is very similar in the Czech and Slovak banking industry. We registered two milestones in the cost efficiency. In 2011 the average efficiency decreased and other decreased in registered in period 2013-2014. We found that this development was caused by the fact that the interest income significantly decreased in balance sheets of most of Czech and Slovak commercial banks. Also Kočišová (2014) registered decreased in cost efficiency in 2012 as a result of financial crisis.

This paper found that in the Czech Republic, the most efficient banks were Česká spořitelna and Sberbank that reached $100 \%$ efficiency. Česká sporitlena is one of the group of the largest banks in the Czech banking sector. On the other hand, Fio banka, PPF banka and Air Bank were the lowest efficient banks in the Czech banking sector. This results are similar the findings of Repková (2012, 2013) who stated that the largest banks were more efficient than medium-sized and small banks in the Czech banking industry. In Slovakia, the most efficient bank was Privatbanka with $100 \%$ efficiency. The lowest efficient banks were Postova banka, Tatrabanka and Slovenska sporitelna. The last mentioned two banks are in group of the largest banks in the Slovak industry. This results are in line with the study of Zimková and Bod'a (2015) who found that the most cost efficient were two largest Slovak commercial banks (Slovenská sporitel'ňa and Všeobecná úvěrová banka). Our results do not confirm all results of Řepková and Miglietti (2014) who concluded that the group of small and medium-sized banks were more efficient than the largest banks.

Next we investigated the reasons of inefficiency for inefficient DMU. The main reason of inefficiency is the excess of clients' deposits in most of commercial banks. Other reason is number of employees and the high value of cost of fixed assets is in Czech Expobank or in Air Bank and in CSOB in Slovakia. Thus the findings of the paper is that inefficient banks would be more efficient if they decreased deposits and number of employees.

Further research would be oriented on using other approach for selection of variables and thus deposits used as an output. Next, it could be more detailed examined the sources of inefficiency and examined the cost efficiency of individual group of banks according the banks' size.

\section{Funding}

This work was supported by the Internal Grant System of the Silesian University [17/2016]. 


\section{References}

Banker, R. D.; Charnes, A.; Cooper, W. W. 1984. Some models for estimating technical and scale inefficiencies in data envelopment analysis, Management Science 30(9): 1078-1092. http://dx.doi.org/10.1287/mnsc.30.9.1078

Benston, G. 1965. Branch banking and economies of scale, Journal of Finance 20(2): 312-331.

http://dx.doi.org/10.1111/j.1540-6261.1965.tb00212.x

Berger, A.; Hanweck, G.; Humphrey, D. 1987. Competitive viability in banking: scale, scope, and product mix economies, Journal of Monetary Economics 20(3): 501-520. http://dx.doi.org/10.1016/0304-3932(87)90039-0

Berger, A.; Mester, L. 1997. Inside the black box: what explains differences in the efficiencies of financial institutions, Journal of Banking and Finance 21: 895-947. http://dx.doi.org/10.1016/S0378-4266(97)00010-1

Berger, A. N.; Humphrey, D. 1997. Efficiency of financial institutions: international survey and directions for future research, European Journal of Operational Research 98: 175-212. http://dx.doi.org/10.1016/S0377-2217(96)00342-6

Berger, A. N.; Mester, L. 2003. Explaining the dramatic changes in performance of US banks: technological change, deregulation, and dynamic changes in competition, Journal of Financial Intermediation 12: 57-95. http://dx.doi.org/10.1016/S1042-9573(02)00006-2

Bod'a, M.; Zimková, E. 2015. Efficieny in the Slovak banking industry: a comparison of three approaches, Prague Economic Papers 24(4): 434451. http://dx.doi.org/10.18267/j.pep.546

Camanho, A.; Dysons., R. G. 2005. Cost efficiency measurement with price uncertainty: a DEA application to bank branch assessments, European Journal of Operational Research 161: 432-446. http://dx.doi.org/10.1016/j.ejor.2003.07.018

Casu, B, Molyneux, P. (2003). A comparative study of efficiency in European banking, Applied Economics 35(17): 1865-1876. http://dx.doi.org/10.1080/0003684032000158109

Charnes, A.; Cooper, W. W.; Rhodes, E. 1978. Measuring the efficiency of decision making units, European Journal of Operational Research 2: 429-444. http://dx.doi.org/10.1016/0377-2217(78)90138-8

Cooper, W. W.; Seiford, L. M.; Tone, K. 2007. Data envelopment analysis: a comprehensive text with models, applications, references and DEA-Solver software. $2^{\text {nd }}$ ed. New York: Springer Science and Business Media.

Farrell, M. J. 1957. The measurement of productive efficiency, Journal of the Royal Statistical Society (Series A) 120(2): 253-281. http://dx.doi.org/10.2307/2343100

Favero, C. A.; Papi, L. 1995. Technical efficiency and scale efficiency in the Italian banking sector: a non- parametric approach, Applied Economics 27(3): 385-395.

http://dx.doi.org/10.1080/00036849500000123

Fries, S.; Taci, A. 2005. Cost efficiency of banks in transition: evidence from 289 banks in 15 post-communist countries, Journal of Banking and Finance 29(1): 55-81.

http://dx.doi.org/10.1016/j.jbankfin.2004.06.016

Hancock, D. 1991. A theory of production for the financial firm. Norwell: Kluwer Academic Publishers. http://dx.doi.org/10.1007/978-94-011-3870-3

Jimborean, R.; Brack, E. 2010. The cost-efficiency of French banks, Bankers, Markets and Investors 105: 21-38.

Kamecka, M., 2010. Bank efficiency in CEE: Doctoral thesis. Vienna: WU Vienna University of Economics and Business.

Kočišová, K. 2014. Application of data envelopment analysis to measure cost, revenue and profit efficiency, Statistika 94(3): 47-57.

Matoušek, R.; Taci, A. 2005. Efficiency in banking: empirical evidence from the Czech republic, Economic Change and Restructuring 37(3): 225-244. http://dx.doi.org/10.1007/s10644-005-5059-4

Řepková, I. 2012. Cost efficiency of the Czech commercial banks, in Proceedings of $13^{\text {th }}$ International Conference on Finance and Banking, 12-13 October 2011, Ostrava, Czech Republic.

Řepková, I. 2013. Cost and profit efficiency of the Czech commercial banks, International Journal of Mathematical Models and Methods in Applied Sciences 7(3): 286-294.

Řepková, I.; Miglietti, C. 2014. Cost and profit efficiency of the Slovak banking sector, in Proceedings of $14^{\text {th }}$ International Conference on Finance and Banking, 16-17 Octover 2013, Ostrava, Czech Republic.

Sealey, C. W.; Lindley, J. T. 1977. Inputs, outputs and a theory of production and cost at depository financial institutions, Journal of Finance 32(8): 1251-1266.

http://dx.doi.org/10.1111/j.1540-6261.1977.tb03324.x

Seiford, L. M; Thrall, R. M. 1990. Recent developments in DEA: the mathematical programming approach to frontier analysis, Journal of Econometrics 46: 738. http://dx.doi.org/10.1016/0304-4076(90)90045-U

Sherman, D. H.; Gold, F. 1985. Bank branch operating efficiency: evaluation with data envelopment analysis, Journal of Banking and Finance 9(3): 297-315. http://dx.doi.org/10.1016/0378-4266(85)90025-1

Stavárek, D.; Polouček, S. 2004. Efficiency and profitability in the banking sector, in Polouček, S. (Ed.). Reforming the financial sector in central european countries. Houndmills: Palgrave Macmillan, 75135.

Tortosa-Ausina, E. 2002. Financial costs, operating costs, and specialization of Spanish banking firms as distribution dynamics, Applied Economics, Taylor and Francis Journals 34(17): 2165-2176. http://dx.doi.org/10.1080/00036840210138400 
Zimková, E. 2015. Cost efficiency of Slovak commercial banks under the standpoint of the intermediation approach, in $18^{\text {th }}$ AMSE Applications of Mathematics and Statistics in Economics, 2-6 September, Jindřichův Hradec, Czech Republic.
Zimková, E.; Bod'a, M. 2015. Cost efficiency of Slovak commercial banks under the standpoint of the production aproach, in The $9^{\text {th }}$ International Days of Statistics and Economics, 10-11 September, Prague, Czech Republic. 